\title{
Neurofilament Proteins and the Mesolimbic Dopamine System: Common Regulation by Chronic Morphine and Chronic Cocaine in the Rat Ventral Tegmental Area
}

\author{
Dana Beitner-Johnson, Xavier Guitart, and Eric J. Nestler \\ Laboratory of Molecular Psychiatry, Departments of Pharmacology and Psychiatry, Yale University School of Medicine, \\ Connecticut Mental Health Center, New Haven, Connecticut 06508
}

The ventral tegmental area (VTA) and its dopaminergic projections appear to mediate some of the rewarding properties of opiates, cocaine, and other drugs of abuse. In a previous study, we demonstrated that chronic morphine and cocaine exert common actions on tyrosine hydroxylase, the ratelimiting enzyme in catecholamine biosynthesis, in this dopaminergic brain reward region (Beitner-Johnson and Nestler, 1991). In the present study, we investigated the effects of chronic morphine and cocaine on other phosphoproteins in the VTA by back phosphorylation and two-dimensional electrophoretic analysis. It was found that a number of phosphoproteins, in addition to tyrosine hydroxylase, were regulated similarly by the two drug treatments in this brain region. Several of these morphine- and cocaine-regulated phosphoproteins were identified as neurofilament (NF) proteins. Chronic, but not acute, administration of either morphine or cocaine was found to decrease levels of the three NF proteins, NF-200 (NF-H), NF-160 (NF-M), and NF-68 (NFL), by between $15 \%$ and $50 \%$ in the VTA by back phosphorylation, immunolabeling, and Coomassie blue staining. Such regulation of NF proteins was selective, in that no detectable changes were observed in the levels of eight other major cytoskeletal or cytoskeletal-associated proteins analyzed. Furthermore, NF levels were not altered by chronic treatment with either imipramine or haloperidol, two psychotropic drugs without reinforcing properties, or by chronic stress. Morphine and cocaine regulation of NFs showed regional specificity, as NF levels were not altered in the substantia nigra, or other parts of the brain or spinal cord, by these drug treatments. NFs are thought to function as determinants of neuronal morphology and to be associated with axonal transport. Thus, decreased NF levels in the VTA in response to chronic morphine and chronic cocaine could lead to drug-induced alterations in the structural and functional properties of this brain region, which may represent, in turn, part of a common biochemical basis of morphine and cocaine addiction and craving.

Received Oct. 11, 1991; revised Dec. 31, 1991; accepted Jan. 6, 1992.

This work was supported by U.S. Public Health Service Grants DA-05490 and DA-07359, by the McKnight Endowment Fund for Neuroscience, by a gift from Eli Lilly, and by the Abraham Ribicoff Research Facilities, Connecticut Mental Health Center, State of Connecticut Department of Mental Health.

Correspondence should be addressed to Dr. Eric J. Nestler, Laboratory of Molecular Psychiatry, Departments of Psychiatry and Pharmacology, Yale University School of Medicine and Connecticut Mental Health Center, 34 Park Street, New Haven, CT 06508 .

Copyright (C) 1992 Society for Neuroscience $0270-6474 / 92 / 122165-12 \$ 05.00 / 0$
The reinforcing properties of drugs of abuse are important components of their addiction liability. Several lines of evidence, based initially on animal self-administration studies, have focused attention on dopaminergic neurons in the ventral tegmental area (VTA) and certain of its projection regions, most notably the nucleus accumbens (NAc), as neural substrates mediating the reinforcing properties of several types of drugs of abuse (for reviews, see Fibiger, 1978; Bozarth, 1986; Wise and Bozarth, 1987; Koob and Bloom, 1988; Liebman and Cooper, 1989). A number of studies have reported that lesions of the VTA and/or NAc attenuate opiate, cocaine, and amphetamine self-administration and conditioned place preference (Lyness et al., 1979; Roberts and Koob, 1982; Spyraki et al., 1983; Pettit et al., 1984; Zito et al., 1985; Bozarth and Wise, 1986; Carr et al., 1989). In addition, virtually all drugs abused by humans, including opiates, cocaine, amphetamine, ethanol, nicotine, and tetrahydrocannabinol, increase dopamine release in the NAc when administered systemically to rats (DiChiara and Imperato, 1988; Chen et al., 1990). These studies identify common acute actions of drugs of abuse on the mesolimbic VTA-NAc pathway that may contribute to their rewarding properties, and implicate the VTA and the NAc as brain regions involved in a common mechanism of drug addiction. Since these addictive drugs have diverse primary sites of action (e.g., distinct cell surface receptors), indirect actions of these drugs on intracellular proteins may be a convergence point at which various drugs of abuse exert similar effects on mesolimbic dopamine function.

Drugs of abuse also have profound chronic effects on brain function. There is growing evidence in animals and in people that chronic use of opiates and psychostimulants increases drug craving (Lett, 1989; Piazza et al., 1989; Jaffe, 1990). Moreover, chronic exposure to these drugs leads to similar types of sensitization to their acute locomotor-activating effects (Babbini and Davis, 1972; Post and Rose, 1976; Kilbey and Ellinwood, 1977). A number of studies support the view that these chronic actions also appear to be mediated, at least in part, via the VTANAc pathway (Kalivas and Duffy, 1988; Koob and Bloom, 1988; IIenry et al., 1989; Pettit et al., 1990; Stekatee et al., 1991), although the precise biochemical and molecular mechanisms involved remain uncertain.

In previous studies, we have shown that chronic morphine and chronic cocaine treatments produce some similar effects on levels of G-proteins, adenylate cyclase, and cAMP-dependent protein kinase in the mesolimbic dopamine system (Nestler et al., 1990b; Terwilliger et al., 1991a). In addition, we have found that chronic morphine and cocaine treatments similarly regulate 
tyrosine hydroxylase in these brain regions (Beitner-Johnson and Nestler, 1991). In the present study, we furthered these investigations by examining the effects of chronic morphine and chronic cocaine on protein phosphorylation in the VTA by use of a back-phosphorylation proccdurc. Back phosphorylation is a well-established procedure with which to study brain phosphoproteins, and provides information about the total levels and phosphorylation state of individual phosphoproteins (Nestler and Greengard, 1984, 1989). Given the important role of protein phosphorylation in the regulation of neuronal function, such studies offer an approach by which to reveal the types of proteins and neuronal processes altered by morphine and cocaine treatment.

We report here the identification of several MCRPPs (morphine- and cocaine-regulated phosphoproteins) and show that MCRPP-200, -160, -68, and -64 are neurofilament (NF) proteins. NFs are neural-specific intermediate filaments that appear to be components of the neuronal cytoskeleton associated with the determination of neuronal morphology and, possibly, axonal transport (Hoffman and Lasek, 1975; Tytell et al., 1981; Hoffman et al., 1984; Hall ct al., 1991). NFs arc found in all, or virtually all, neurons in the CNS and PNS (Robinson and Anderton, 1988). The finding that these proteins, like tyrosine hydroxylase, are similarly altered in the VTA by chronic morphine and chronic cocaine suggests that these drug treatments induce common functional changes within the VTA. Possible functional sequelae mediated via such drug regulation of NFs, which could represent part of a general biochemical mechanism underlying opiate and cocaine addiction and craving, are discussed.

\section{Materials and Methods}

In vivo drug treatments. Male Sprague-Dawley rats (initial weight, 140$180 \mathrm{gm}$; obtained from CAMM, Wayne, NJ) were used in these studies. Chronic morphine was administered as described previously (Guitart and Nestler, 1989). Briefly, rats received one $75 \mathrm{mg}$ pellet of morphine base (NIDA) subcutaneously under light halothane anesthesia daily for $5 \mathrm{~d}$, and experiments were performed on day six. In initial studies, control rats were implanted with equivalent placebo pellets (NID $\Lambda$ ). $\Lambda \mathrm{s}$ in previous studies (Guitart and Nestler, 1989), we found that placebo pellets produced no changes in any phosphoproteins as compared to naive control rats; hence, subsequent experiments were performed using naive animals as controls. For chronic cocaine studies, rats were injected with cocaine hydrochloride ( $15 \mathrm{mg} / \mathrm{kg}$; Sigma) intraperitoneally in $0.9 \%$ saline twice daily for $14 \mathrm{~d}$. Control rats received equivalent saline injections. In most experiments, the animals were used on day $15,30 \mathrm{~min}$ after the last A.M. injection. In some experiments, the animals were used on day $15, \sim 16 \mathrm{hr}$ after the previous P.M. injection. Similar results were obtained under these two treatment conditions. These treatment protocols are similar to those used in previous studies, where they have been shown to induce states of opiate tolerance and dependence in the case of morphine (Blasig et al., 1973; Aghajanian, 1978; Rasmussen et al., 1990), and behavioral sensitization as well as electrophysiological and neurochemical alterations in mesolimbic dopamine neurons in the case of cocaine (Kilbey and Ellinwood, 1977; Henry et al., 1989; Lett, 1989; Brock et al., 1990; Pettit et al., 1990; Beitner-Johnson and Nestler, 1991; $\mathrm{Ng}$ et al., 1991). For chronic imipramine treatment, rats received intraperitoneal injections of imipramine $(15 \mathrm{mg} / \mathrm{kg}$; Sigma) once daily for $18 \mathrm{~d}$. Control animals received saline injections, and rats were used on day 19. This administration protocol has been shown in previous studies to lead to chronic effects of imipramine on noradrenergic neurons of the locus coeruleus (LC; Nestler et al., 1990a). For chronic haloperidol treatment, rats were administered $1 \mathrm{mg} / \mathrm{kg}$ haloperidol orally (in the drinking water) for $21 \mathrm{~d}$ and were used on day 22. This protocol has been shown to induce depolarization inactivation of midbrain dopaminergic neurons (Chiodo and Bunney, 1983).

Chronic cold stress. Rats were housed three per cage in wirc mesh cages $(35 \times 20.5 \times 17 \mathrm{~cm})$ in a colony room for at least $7 \mathrm{~d}$ prior to the start of the experiment. The room was maintained on a $12 \mathrm{hr}$ light/
$12 \mathrm{hr}$ dark cycle, and rats were allowed access to food and water ad libitum. Control rats remained in the colony room throughout the study. Rats exposed to cold stress were housed singly in plastic cages $(28 \times$ $15 \times 15 \mathrm{~cm}$ ) in a cold room maintained at $3-5^{\circ} \mathrm{C}$ for $5 \mathrm{~d}$ exactly as described by Melia et al. (1992). Rats were used in the morning of day 6 .

Isolation of brain regions. Brains were removed rapidly from decapitated rats and cooled immediately in ice-cold buffer containing 126 $\mathrm{mM} \mathrm{NaCl}, 5 \mathrm{~mm} \mathrm{KCl}, 1.25 \mathrm{~mm} \mathrm{NaH} \mathrm{PO}_{4}, 25 \mathrm{~mm} \mathrm{NaHCO}, 2 \mathrm{~mm}$ $\mathrm{CaCl}_{2}, 2 \mathrm{mM} \mathrm{MgCl}$, and $10 \mathrm{~mm}$ D-glucose, pH 7.4. The VTA, substantia nigra (SN), and LC were obtained from $1 \mathrm{~mm}$ coronal cross sections using a Mcllwain tissue slicer. Nuclei were excised from the slices using a 15 gauge syringe needle as described previously (Nestler and Tallman, 1988; Palkovits and Brownstein, 1988); bilateral punches (about $1.5 \mathrm{mg}$ wet weight) were pooled from individual rats. The spinal cord and other brain regions were removed by gross dissection.

Back-phosphorylation assays, two-dimensional electrophoresis, and peptide mapping. Samples were prepared for direct back phosphorylation as described previously (Guitart and Nestler, 1989) with minor modifications. Brieffy, brain punches were sonicated using a Kontes cell disrupter in $100 \mu \mathrm{l}$ of an ice-cold buffer containing $20 \mathrm{~mm}$ citric acid and $0.01 \%$ Nonidet P-40, followed by the addition of another $100 \mu \mathrm{l}$ of the same buffer. This method permitted easy sonication in a small volume, with a final $\mathrm{pH}$ of 2.8-3.0. The acidified homogenates were centrifuged at $10,000 \times g$ in a Savant microfuge for $15 \mathrm{~min}$ at $4^{\circ} \mathrm{C}$. The pellets were discarded and the supernatants ("acid extracts") were neutralized to $\mathrm{pH} 6.0-6.3$ by the addition of $300 \mu \mathrm{l} / \mathrm{ml}$ of $200 \mathrm{mM} \mathrm{Na}{ }_{2} \mathrm{HPO}_{4}$.

Back phosphorylation was performed as described previously (Guitart and Nestler, 1989), using purified catalytic subunit of cAMP-dependent protein kinase (Sigma) and $\gamma^{-32} \mathrm{P}-\mathrm{ATP}(30 \mathrm{Ci} / \mathrm{mmol}$; New England $\mathrm{Nu}-$ clear). Final protein concentrations were typically $0.5-1.0 \mu \mathrm{g} / \mu \mathrm{l}$, and equivalent amounts of back-phosphorylated extracts (containing 5-20 $\mu \mathrm{g}$ of protein) were subjected to two-dimensional gel electrophoresis as described (O'Farrell, 1975; Guitart and Nestler, 1989), with two modifications made in the isoelectric focusing protocol. First, LKB ampholines were substituted for Bio-Rad ampholines, as the former were found to be more stable and to produce better resolution in the isoelectric focusing dimension. These were used in the same ratio as described previously (4\% ampholines, $1: 1 \mathrm{pH} 3.5-10: \mathrm{pH} 5-7$ ). Second, piperazine diacrylamide (Bio-Rad) was substituted for bisacrylamide as a crosslinking agent in the first dimension on a gram-for-gram basis. This was found to increase the strength and ease of handling of the tube gels, without altering the relative migration of individual phosphoproteins.

Identity between phosphoproteins identified on one- and two-dimensional gels by back phosphorylation was studied by one-dimensional peptide mapping analysis as described by Cleveland ct al. (1977). Bands of individual phosphoproteins were excised from dried one- or twodimensional gels and reswelled in $20 \mathrm{~mm}$ Tris pH $6.7,0.1 \%$ SDS for $10 \mathrm{~min}$ at room temperature. The gel bands were then loaded onto standard one-dimensional SDS-polyacrylamide gels except that the stacking gels were $6 \mathrm{~cm}$ long and the resolving gels contained $15 \%$ acrylamide $/ 0.6 \%$ bisacrylamide. Staphylococcus aureus V-8 protease ( $2.5 \mu \mathrm{g}$; Miles) was then loaded on top of the bands, and the gels were electrophoresed at $60 \mathrm{~V}$ overnight. Resulting gels were dried and autoradiographed.

Quantitation of back-phosphorylation data. Phosphorylated proteins were detected by autoradiography at room temperature for $12-72 \mathrm{hr}$. In each experiment, four control and four drug-treated rats were used, and each brain sample was analyzed in duplicate (i.e., duplicate back phosphorylation and two-dimensional gels). The amount of ${ }^{32} \mathrm{P}$ incorporated into individual bands was quantitated using 60 min scans of dried gels on a Betascope blot analyzer (Betagen). Back-phosphorylation levels of individual proteins derived from drug-treated rats were calculated as a percentage of the average levels from control rats.

Immunolabeling of neurofilaments and other proteins. Tissue samples were homogenized ( $10 \mathrm{mg}$ wet weight $/ \mathrm{ml}$ ) in $2 \%$ SDS, and protein levels were determined using the method of Lowry et al. (1951). For onedimensional immunoblotting, samples were adjusted to contain final concentrations of $50 \mathrm{~mm}$ Tris $\mathrm{pH} 6.7,4 \%$ glycerol, $4 \%$ SDS, and $2 \%$ 2-mercaptoethanol, with bromophenol blue as a marker, and then boiled for $2 \mathrm{~min}$. Aliquots (containing $10-40 \mu \mathrm{g}$ protein) were subjected to one-dimensional SDS-polyacrylamide gel electrophoresis with $6 \%$ acrylamide $/ 0.24 \%$ bisacrylamide in the resolving gels. For two-dimensional immunoblotting, gel samples were prepared and electrophoresed exactly as described (O'Farrell, 1975; Guitart and Nestler, 1989), except that $100-150 \mu \mathrm{g}$ of protein were loaded onto gels, and $0.03 \%$ SDS and 


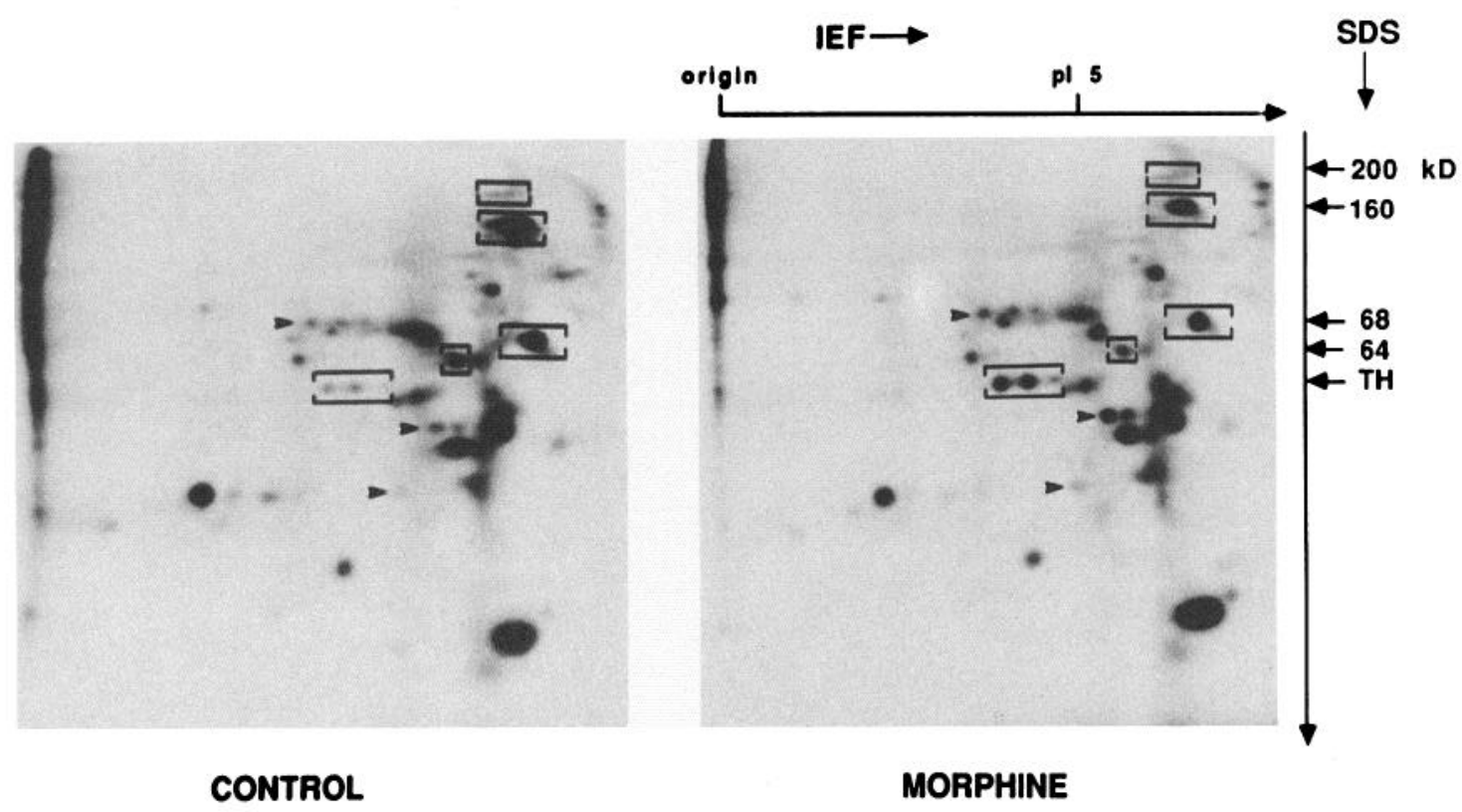

Figure 1. Autoradiograms of two-dimensional gels illustrating the effect of chronic morphine on back phosphorylation in the VTA. Rats were treated chronically with morphine as described in Materials and Methods. Isolated VTA nuclei from control and drug-treated rats were then subjected to back phosphorylation with cAMP-dependent protein kinase and $\gamma-{ }^{32} \mathrm{P}$-ATP and to two-dimensional gel electrophoresis, as described. Resulting gels were dried and autoradiographed. Brackets indicate the positions of phosphoproteins of $M, 200,160,68$, and 64 whose back phosphorylation is decreased by both chronic morphine and chronic cocaine (see Fig. 2), and also indicate the position of a $58 \mathrm{kDa}$ phosphoprotein [known to be tyrosine hydroxylase $(T H)$ ] whose back phosphorylation is increased by chronic morphine and chronic cocaine. Several other unknown phosphoproteins of 71,51 , and $39 \mathrm{kDa}$ (indicated by arrowheads), which are not studied further here, also appeared to be regulated by morphine and cocaine.

4\% Nonidet P-40 (final concentrations) were included in the isoelectric focusing dimension to facilitate sample solubilization. Proteins were transferred electrophoretically from one- and two-dimensional gels to nitrocellulose papers. When immunolabeling NF-200 and NF-160, $0.025 \%$ SDS was included in the transfer buffer, as this was found to increase the efficiency of the electrophoretic transfer process. Nitrocellulose papers were then incubated with $2 \%$ nonfat dry milk (or $1 \%$ goat serum; GIBCO, in the case of the SMI-31 antibody) in a buffer containing $10 \mathrm{~mm}$ sodium phosphate, $\mathrm{pH} 7.2,140 \mathrm{~mm} \mathrm{NaCl}$, and $0.05 \%$ Tween 20 (Sigma). NFs were then immunolabeled using the following antibodies: anti-NF-200 (clone N52, 1:1000; Sigma), anti-NF-160 (clone NN18, 1:750; Sigma), anti-NF-68 (clone NR4, 1:500; Boehringer Mannheim), anti-NF-66 (1:10,000; kindly provided by Dr. F.-C. Chiu, Albert Einstein College of Medicine), and anti-highly phosphorylated NF-200/160 (clone SMI-31, 1:5000; Sternberger Monoclonals, Inc). Antibodies to other cytoskeletal proteins were used as follows: anti- $\alpha$ tubulin (clone DM1A, 1:1000; ICN), anti- $\beta$-tubulin (clone TUB 2.1, 1 : $250 ; \mathrm{ICN})$, anti-actin (1:500; Sigma), anti-tropomyosin (1:500; Sigma), anti-tau (1:1000; Sigma), anti-synaptophysin (clone SY38, 1:1000; Boehringer Mannheim), anti-vimentin (clone V9, 1:500; Sigma), and anti-synapsin I (1:1000; kindly provided by Drs. A. Czernik and P. Greengard, Rockefeller University). Immunolabeling was detected with ${ }^{125} \mathrm{I}$-labeled goat anti-mouse Ig (or ${ }^{125} \mathrm{I}$-labeled goat anti-rabbit IgG, in the case of anti-NF-66, anti-synapsin, anti-tau, anti-tropomyosin, and anti-actin antibodies) $(500 \mathrm{cpm} / \mu \mathrm{l}$; New England Nuclear). The resulting blots were autoradiographed with the use of intensifying screens (DuPont), and levels of immunolabeling were quantitated by densitometric scanning of autoradiograms.

Coomassie blue staining analysis of neurofilaments. For Coomassie blue staining, lanes on one-dimensional gels were loaded with $60-100$ $\mu \mathrm{g}$ of protein and the gels were then stained for $2-4 \mathrm{hr}$ with $0.125 \%$ Coomassie brilliant blue $\mathrm{R}$ (Sigma) in $50 \%$ methanol/10\% acetic acid (v/v). Gels were then destained for $1 \mathrm{hr}$ in $50 \%$ methanol/10\% acetic acid and then for $2-3 \mathrm{hr}$ in several changes of a solution containing $5 \%$ methanol $/ 7 \%$ acetic acid. After destaining the gels, NF levels were quantitated by densitometric scanning of wet gels using a GSXL laser-enhanced densitometer (LKB). It was determined that NF levels were linear over a fivefold concentration range of brain tissue used, as measured by densitometric analysis.

\section{Results}

Chronic morphine and cocaine regulation of 200, 160,68, and $64 \mathrm{kDa}$ phosphoproteins

Figure 1 shows autoradiograms of two-dimensional gels that illustrate the effect of chronic morphine treatment on back phosphorylation in the VTA. While the overall phosphoprotein pattern in control and morphine-treated rats was very similar, a number of individual phosphoproteins were consistently altered by chronic morphine treatment. Chronic morphine significantly decreased the back-phosphorylation levels of four phosphoproteins of $200,160,68$, and $64 \mathrm{kDa}$. These data are presented in numerical form in Table 1. It can also be seen in Figure 1 that a $58 \mathrm{kDa}$ phosphoprotein known to be tyrosine hydroxylase is increased by chronic morphine, as has been reported previously (Beitner-Johnson and Nestler, 1991). In addition, chronic morphine regulated several other as yet unknown phosphoproteins of $M_{r} 39,51$, and $71 \mathrm{kDa}$.

Interestingly, chronic cocaine was found to regulate the 200 , 160,68 , and $64 \mathrm{kDa}$ phosphoproteins in the same way as chronic morphine in the VTA. In Figure 2, autoradiograms of twodimensional gels show that chronic cocaine decreased backphosphorylation levels of these four phosphoproteins in this brain region. Numerical data are presented in Table 1. Chronic cocaine also appeared to regulate tyrosine hydroxylase as well as several other unknown phosphoproteins of 39,51 , and 71 $\mathrm{kDa}$ regulated by chronic morphine (see Figs. 1, 2). We have designated these various proteins as MCRPPs (morphine- and cocaine-regulated phosphoproteins).

Neither a single acute dose of morphine $(10 \mathrm{mg} / \mathrm{kg}$ of morphine sulfate, s.c.) nor a single acute dose of cocaine $(15 \mathrm{mg} /$ $\mathrm{kg}$, i.p.) with rats used $30 \mathrm{~min}$ later produced consistent alter- 


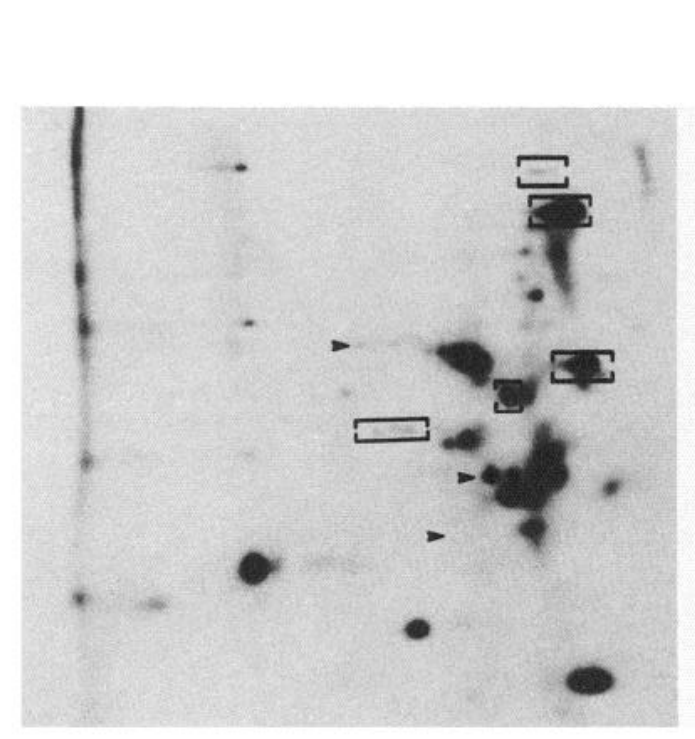

CONTROL

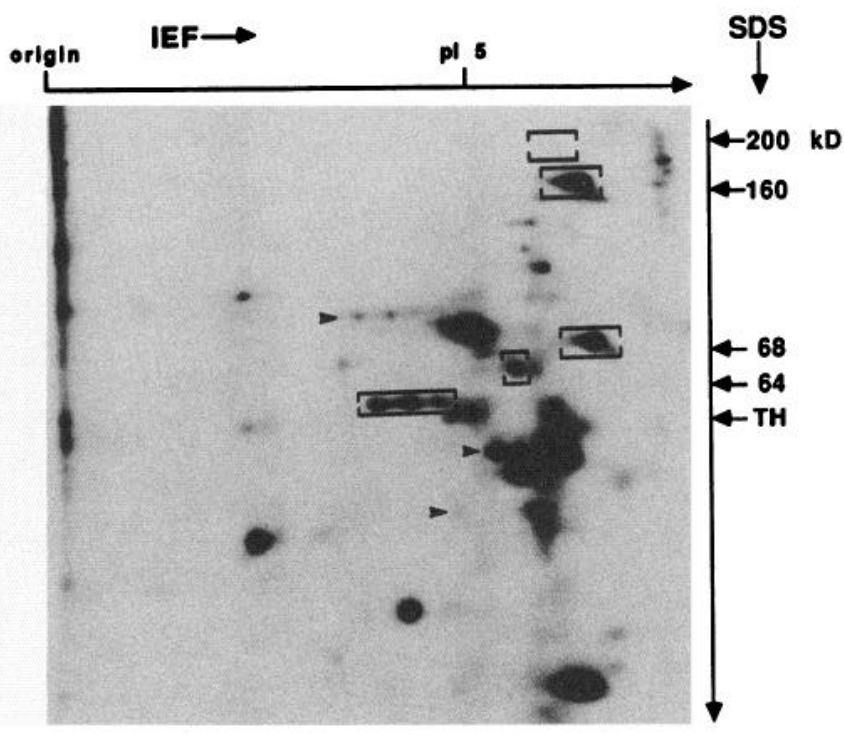

COCAINE

Figure 2. Autoradiograms of two-dimensional gels illustrating the effect of chronic cocaine on back phosphorylation in the VTA. Rats were treated chronically with cocaine as described in Materials and Methods. Isolated VTA nuclei were then subjected to back phosphorylation and twodimensional gel electrophoresis, as in Figure 1. Brackets indicate the positions of phosphoproteins of $M, 200,160,68$, and 64 whose back phosphorylation is decreased by both chronic cocaine and chronic morphine (see Fig. 1), and also indicate the position of a $58 \mathrm{kDa}$ phosphoprotein [known to be tyrosine hydroxylase $(T H)$ ] whose back phosphorylation is increased by chronic cocaine and chronic morphine. Several other unknown phosphoproteins of 39,51 , and $71 \mathrm{kDa}$ (indicated by arrowheads), which are not studied further here, also appeared to be regulated by cocaine and morphine.

ations in phosphoprotein levels in the VTA (data not shown). These findings indicate that chronic drug treatment is necessary to produce the changes reported above.

\section{Identification of MCRPP-200, -160, -68, and -64 as NF proteins}

MCRPP-200, -160, and -68 were relatively abundant proteins, as they were easily detectable by Coomassie blue staining of two-dimensional gels (Fig. $3 B$ ). Moreover, given the $M_{r}$ of these phosphoproteins and their strongly acidic isoelectric points on two-dimensional gels, it was considered that they could represent NF proteins (see Brown et al., 1981; Tytell et al., 1981). The phosphoproteins were also found to be present at high levels in spinal cord, as measured by back phosphorylation and twodimensional gel analysis (gels not shown; see below), which further supported the possibility that these could be NF proteins. The identity of the 200,160 , and $68 \mathrm{kDa}$ phosphoproteins as NFs was confirmed by use of specific antibodies (Fig. $3 C-E$ ). It was found that immunolabeled NF-200 (NF-H) comigrates exactly with the $200 \mathrm{kDa}$ phosphoprotein on two-dimensional gels. Likewise, the NF-160 (NF-M) and NF-68 (NF-L) immunolabeled spots comigrate with the 160 and $68 \mathrm{kDa}$ phosphoproteins, respectively. In some experiments, VTA acid extracts, which had been previously labeled with ${ }^{32} \mathrm{P}$ by back phosphorylation, were ${ }^{125} \mathrm{I}$-immunolabeled for NFs (gels not shown). This double-labeling method confirmed that the electrophoretic po- sitions of NF-200, NF-160, and NF-68 corresponded exactly to those of MCRPP-200, -160 , and -68 .

MCRPP-64 was not sufficiently abundant to be visualized on Coomassie blue-stained gels. However, like the other three major NF proteins, this phosphoprotein was also present at high levels in spinal cord. The possibility was then considered that MCRPP-64 could also be an NF (or NF-related) protein. As shown in Figure $3 F$, using two-dimensional immunolabeling techniques, it was determined that this phosphoprotein corresponds to NF-66, a novel NF subunit (Chiu et al:, 1989). Using the double-labeling method described above, antiserum to NF66 (also known as $\alpha$-internexin; Flienger et al., 1990) labeled a protein that comigrated exactly with MCRPP-64. By using a narrow range of ampholines in the isoelectric focusing dimension (4\% ampholines, 1:10 pH 3.5-10: $\mathrm{pH} 4-6)$, three apparent isoforms of this protein were resolved, as shown in the inset to Figure $3 F$. Antiserum to NF-66 labeled one major immunoreactive form and two slightly more acidic minor immunoreactive forms. By double-labeling VTA acid extracts with ${ }^{32} \mathrm{P}$ and ${ }^{125} \mathrm{I}$-secondary antibody, it was determined that the major immunoreactive isoform represents nonphosphorylated NF-66, and the two acidic isoforms correspond to ${ }^{32} \mathrm{P}$-labeled phosphoproteins that yield phosphopeptide maps identical to those derived from MCRPP-64 on two-dimensional gels run under standard isoelectric focusing conditions (not shown). This finding corroborates a previous report of the existence of an acidic

Figure 3. Identification of MCRPP-200, $-160,-68$, and -64 as NFs. A, Aliquots of VTA acid extracts were subjected to back phosphorylation with purified cAMP-dependent protein kinase and $\gamma-{ }^{32} \mathrm{P}-\mathrm{ATP}$ and to two-dimensional gel electrophoresis. Gels were then stained with Coomassie blue, destained, dried, and autoradiographed, as described in Materials and Methods. Autoradiogram of a representative gel is shown. $B$, Photograph of a Coomassie blue-stained gel, prepared as described in $A$. $C$, Aliquots of VTA acid extracts were subjected to back phosphorylation as described 

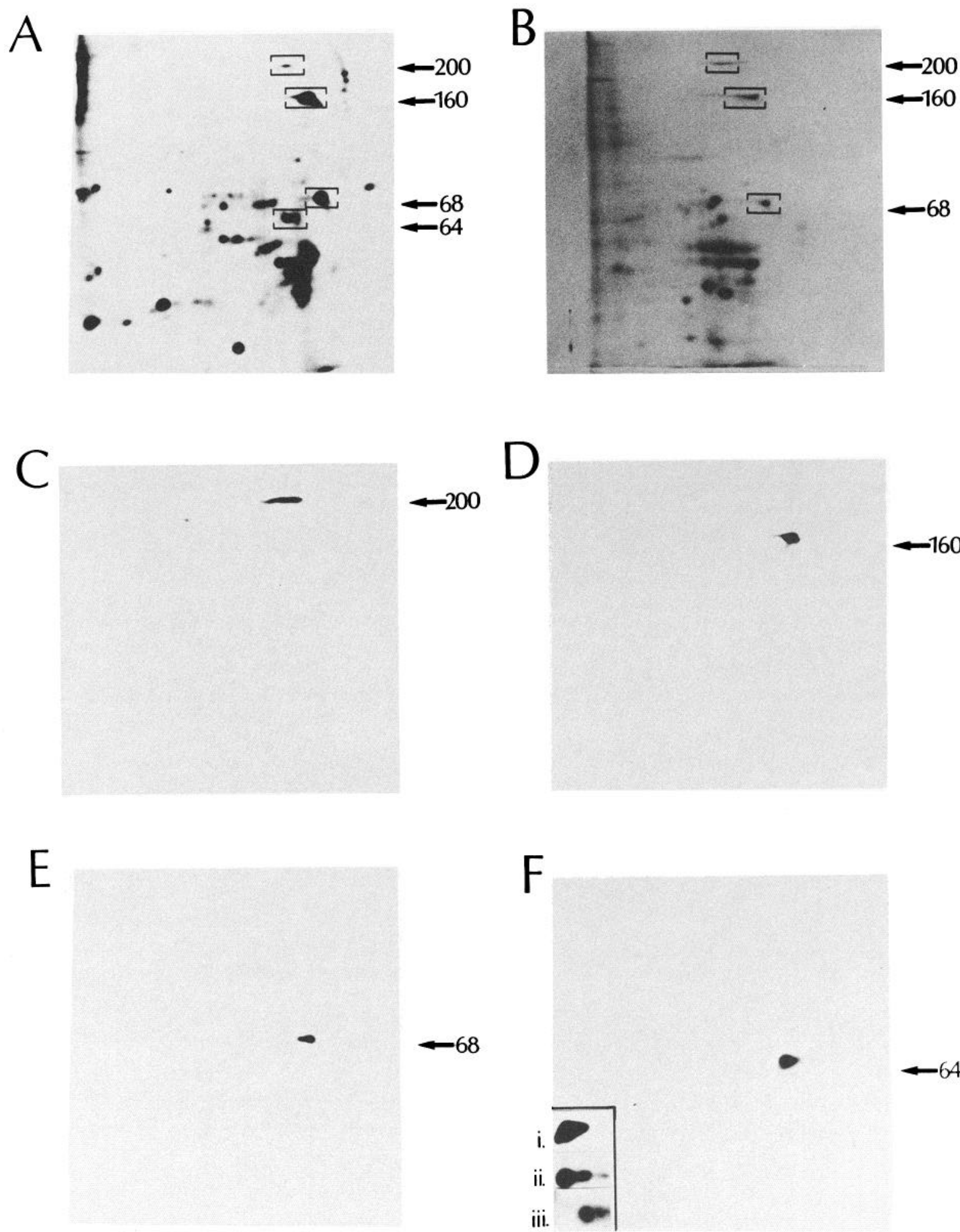

above but with non-radioactively labeled ATP and subjected to two-dimensional gel electrophoresis. Proteins were then transferred electrophoretically to nitrocellulose papers and immunolabeled for NF-200, as described in Materials and Methods. Autoradiogram of a representative twodimensional immunoblot is shown. $D$, Aliquots of VTA acid extracts were prepared as described in $C$ and immunolabeled for NF-160. $E$, Aliquots of VTA acid extracts were prepared as described in $C$ and immunolabeled for NF-68. $F$, Aliquots of VTA acid extracts were prepared as described in $C$ and immunolabeled for NF-66. Inset, Portions of autoradiograms of two-dimensional gels run under "narrow range" isoelectric focusing conditions (4\% ampholines, $1: 10 \mathrm{pH} 3.5-10: \mathrm{pH} 4-6)$ illustrating the effect of phosphorylation on NF-66. $i$, NF-66 immunoreactivity in nonphosphorylated VTA acid extracts. $i$, NF-66 immunoreactivity in VTA acid extracts that were back phosphorylated with unlabeled ATP. iii, ${ }^{32}$ P-labeled MCRPP-64 in VTA acid extracts back phosphorylated as $i i$, but in the presence of $\gamma-{ }^{32}$ P-ATP. The brackets in gel $A$ identify the position of MCRPP$200,-160,-68$, and -64 . The figure shows that these phosphoproteins comigrate with Coomassie blue-stained NF proteins and immunolabeled NF-200, $-160,-68$, and -66 . 
Figure 4. Autoradiograms illustrating the effect of chronic morphine and chronic cocaine on levels of NF immunoreactivity. $A$ and $B$, Rats were treated chronically with morphine $(A)$ or cocaine $(B)$ as described in Materials and Methods. The VTA and SN were isolated from control $(-)$ or drug-treated (+) rats and then 25-40 $\mu \mathrm{g}$ (VTA) or $40-60 \mu \mathrm{g}$ (SN) of crude homogenates were subjected to SDS-PAGE and immunolabeled for NF-200, NF-160, and NF-68.

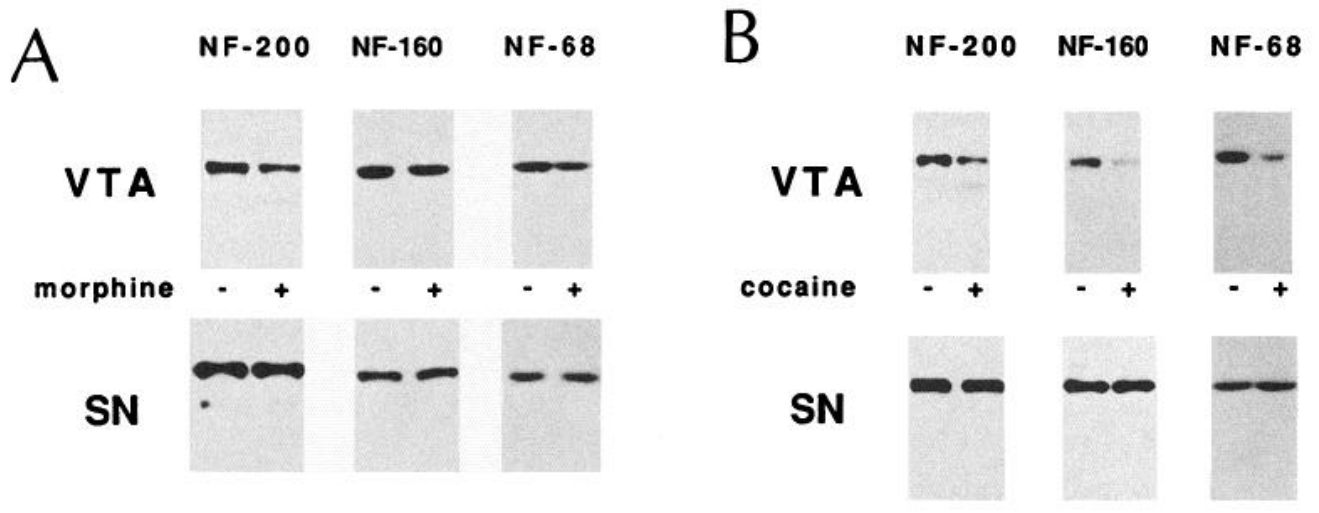

variant of this protein on two-dimensional gels (Nixon et al., 1990).

\section{Chronic morphine and cocaine regulation of $N F$ immunoreactivity and Coomassie blue staining}

Identification of these phosphoproteins as NFs enabled us to study morphine and cocaine regulation of NFs in more detail using immunolabeling techniques. This is important because back phosphorylation could reflect changes in the phosphorylation state or total amounts of these proteins, or both (see Guitart and Nestler, 1989). Chronic morphine or chronic cocaine decreased levels of NF-200, NF-160, and NF-68 immunoreactivity in the VTA to a degree roughly comparable to the decreases measured by back phosphorylation. These findings are shown in Figure 4, with the data presented in numerical form in Table 1.

Because NFs could be readily visualized on two-dimensional Coomassie blue-stained gels, as demonstrated in Figure $3 B$, attempts were made to detect NF-200, NF-160, and NF-68 as Coomassie blue-stained bands on one-dimensional gels as has been reported previously (Brown et al., 1981; Tytell et al., 1981). The identity of the one-dimensional bands as NFs was indicated by the following observations (not shown). First, prominent phosphoproteins of 200,160 , and $68 \mathrm{kDa}$ comigrated exactly with the Coomassie blue-stained proteins. Second, each of these phosphoproteins yielded one-dimensional peptide maps indistinguishable from the 200,160 , and $68 \mathrm{kDa}$ bands resolved on two-dimensional gels. Third, the phosphorylated and Coomassie blue-stained bands showed identical regional distributions; for example, both were present in the VTA and spinal cord at much higher levels than in whole cerebral cortex, consistent with what is known about the regional distribution of NF proteins (see Robinson and Anderton, 1988; Hammerschlag and Brady, 1989).

Morphine- and cocaine-induced decreases in NF-200, NF160 , and NF-68 in the VTA could be visualized on Coomassie blue-stained gels, as illustrated in Figure 5 . These data are presented in numerical form in Table 1. Coomassie blue staining analysis of NFs has the advantage over immunolabeling procedures of bypassing any possible drug-induced alterations in immunogenicity due to changes in phosphorylation, as many antibodies to NFs selectively recognize specific phosphorylation states (Sternberger and Sternberger, 1983; Carden et al., 1985; Lee et al., 1987). Indeed, this may explain why the effects of chronic morphine and cocaine were generally most consistent and robust by Coomassie blue staining (see Table 1).

In addition to decreasing the total amounts of NF proteins, we next considered the possibility that chronic morphine or cocaine might also alter the phosphorylation state of the proteins. We examined this directly by using an antibody specific for highly phosphorylated states of NF-200 and NF-160 (SMI31; Sternberger Monoclonals Inc.). VTA homogenates from rats treated chronically with morphine or cocaine were immunolabeled with this antibody. We found that, in contrast to a decrease

Table 1. Morphine and cocaine regulation of NF proteins in the VTA

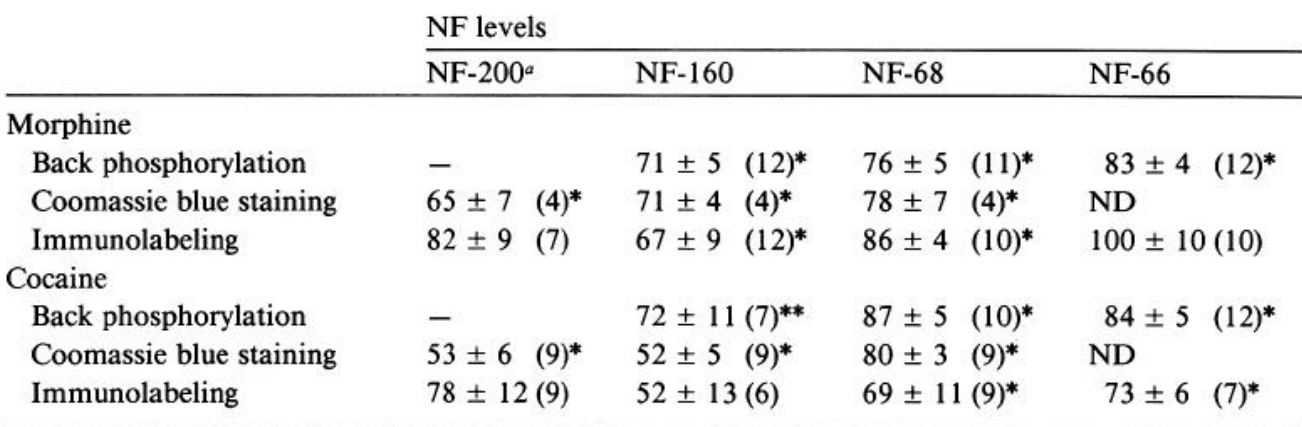

Data are presented as percentage of control $\pm \mathrm{SEM} ; N$ is given in parentheses. ND, not detectable by Coomassie staining.

a Back phosphorylation of NF-200 was not quantified due to variability in the resolution of this phosphoprotein on twodimensional gels, presumably due to its high degree of phosphorylation, as described previously by Julien and Mushynski (1982).

${ }^{*} p<0.05$ by $\chi^{2}$ test.

** $p \approx 0.06$ by $\chi^{2}$ test. 


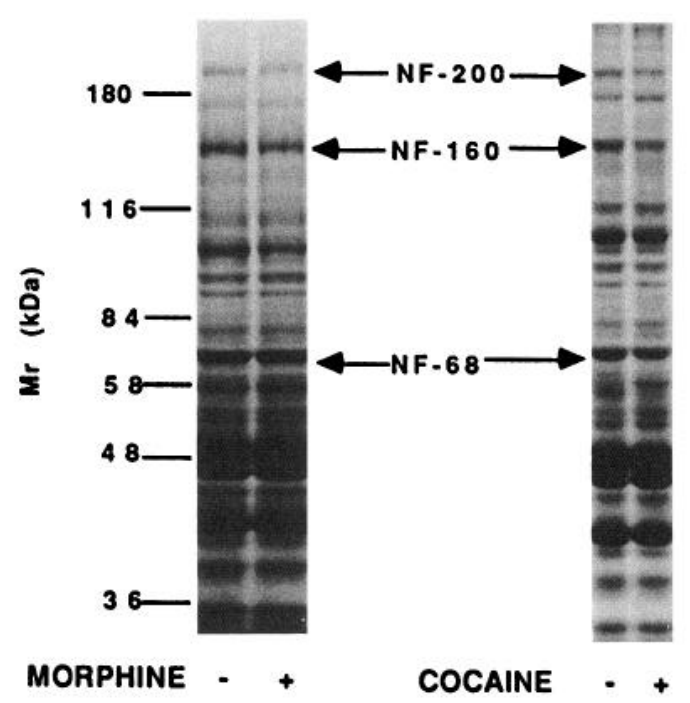

Figure 5. Photographs of Coomassie blue-stained gels illustrating the effects of chronic morphine and chronic cocaine on NF-200, NF-160, and NF-68 in the VTA. Rats were treated chronically with morphine or cocaine, as described in Materials and Methods. Total cellular extracts of VTA were isolated from control $(-)$ and drug-treated $(+)$ rats and subjected to SDS-PAGE and Coomassie blue staining. Arrows indicate the positions of NF proteins.

in Coomassie blue staining (Fig. 5) and total immunoreactivity (Fig. 4) of NFs in the VTA, levels of NF-200 and NF-160 were not decreased by chronic morphine or chronic cocaine treatment as measured by SMI-31 immunolabeling. In fact, there was a tendency for morphine and cocaine to increase SMI-31 immunolabeling (Fig. 6). This suggests that although the total amount of NFs is decreased in the VTA by chronic morphine and cocaine, the remaining NFs exist in a much more highly phosphorylated state than in the controls.

NF-66 (which was not discernable on one-dimensional gels by Coomassie blue staining) was also analyzed by immunolabeling in the VTA after chronic morphine and cocaine treatments. It was found that chronic cocaine significantly decreased NF-66 immunoreactivity in the VTA, whereas chronic morphine did not alter levels of this protein (Fig. 7, Table 1). This cocaine-induced decrease in NF-66 immunoreactivity could account for the decreased levels of the protein observed by back phosphorylation. In contrast, the morphine-induced decrease in NF-66 back phosphorylation, without a change in the total amount of the protein, could indicate that morphine decreases levels of dephospho-NF-66, that is, increases the phosphorylation state of the protein (see Guitart and Nestler, 1989). Thus, unlike NF-200, NF-160, and NF-68, NF-66 appears to be regulated differently in the VTA by chronic morphine and chronic cocaine.

\section{Lack of effect of chronic morphine on other cytoskeletal-associated proteins in the VTA}

It was of interest to determine whether chronic morphine and cocaine were selectively altering NFs in the VTA, or if other cytoskeletal or cytoskeletal-associated elements in neurons might also be disrupted by these drug treatments. To study these possibilities, levels of a number of other proteins were analyzed by immunoblotting in the VTA of rats treated chronically with morphine (Fig. 8). There were no detectable changes in levels of $\alpha$ - or $\beta$-tubulin, the major components of microtubules; in
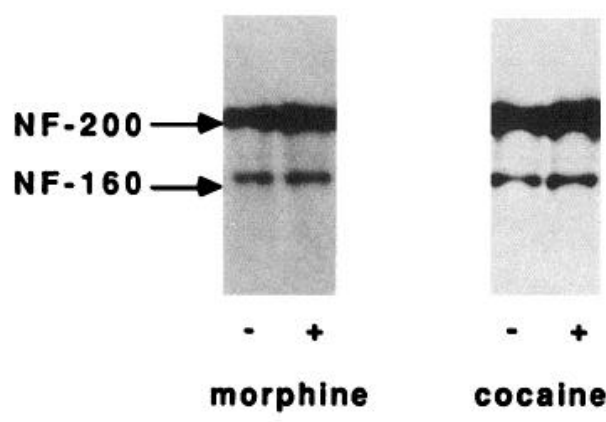

Figure 6. Autoradiograms illustrating the effec، of chronic morphine and chronic cocaine on levels of highly phosphorylated NF-200 and NF-160 immunoreactivity. Rats were treated chronically with morphine or cocaine, as described in Materials and Methods. Total cellular extracts of VTA were isolated from control (-) or drug-treated (+) rats, and aliquots containing $10 \mu \mathrm{g}$ of protein were subjected to SDS-PAGE and immunolabeled for SMI-31, as described in Materials and Methods.

tau, a microtubule-associated phosphoprotein; in actin, the major constituent of microfilaments; or in tropomyosin, a major actin-binding protein. In addition, vimentin, an intermediatefilament phosphoprotein that is structurally related to NFs but is also found in non-neural tissues, was not changed by morphine treatment. Levels of two synaptic vesicle-associated phosphoproteins, synaptophysin and synapsin I, were also unchanged in response to chronic morphine.

\section{Regional specificity of morphine and cocaine regulation of NFs}

It was important to determine whether morphine- and cocaineinduced decreases in NFs were specific to the VTA, or whether this effect was more widespread. It was found that NFs were not altered by chronic morphine in any other region examined, which included the SN (see Figure 4), the brain's other major dopaminergic nucleus; the LC, the major noradrenergic nucleus in brain; and spinal cord, which contains high levels of NFs (Table 2). In addition, NF levels did not appear to be altered by chronic morphine in whole cerebral cortex, though a quantitative analysis of NF levels in crude homogenates of cerebral cortex was not feasible, due to the much lower prevalence of NFs in this brain region (see Robinson and Anderton, 1988; Hammerschlag and Brady, 1989). To assess further the localization of morphine and cocaine regulation of NFs in the VTA,

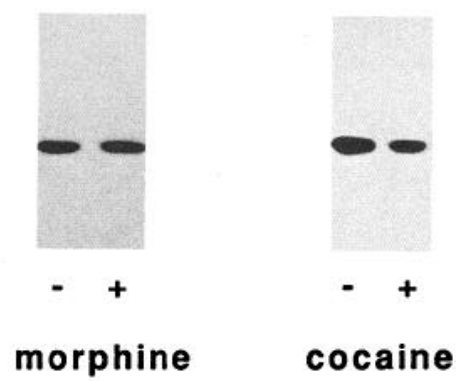

Figure 7. Autoradiograms illustrating the effect of chronic morphine and chronic cocaine on levels of NF-66 immunoreactivity. Rats were treated chronically with morphine or cocaine, as described in Materials and Methods. Total cellular extracts of VTA were isolated from control $(-)$ and drug-treated $(+)$ rats and subjected to SDS-PAGE and immunolabeling for NF-66, as described in Materials and Methods. 
Figure 8. Lack of effect of chronic morphine on cytoskeletal or cytoskeletal-associated proteins in the VTA. Total cellular extracts of VTA, isolated from control $(-)$ or morphine-treated $(+)$ rats, were subjected to SDS-PAGE and immunolabeled for $\alpha$ - and $\beta$-tubulin, tau, actin, tropomyosin, vimentin, synaptophysin, or synapsin I.

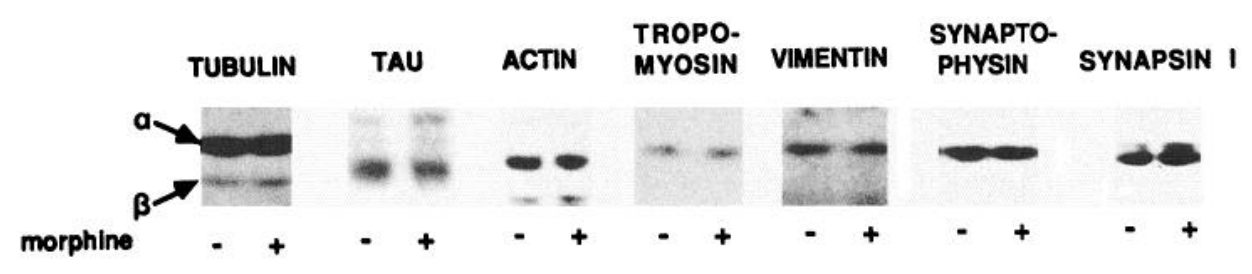

several portions of the midbrain were analyzed. The VTA and $\mathrm{SN}$ were removed from midbrain cross sections of control and morphine-treated rats using a 15 gauge syringe needle (i.d., 1 $\mathrm{mm}$ ), as described in Materials and Methods. After removal of these nuclei, the area immediately surrounding the 15 gauge punch of the VTA was excised using a 12 gauge syringe needle (i.d., $2 \mathrm{~mm}$ ), resulting in a doughnut-shaped ring of tissue. This "doughnut" and the remaining tissue in the midbrain cross section were then analyzed for NFs. Chronic morphine did not alter NFs in either the doughnut or in the remaining midbrain cross section (Table 2). In contrast to very high levels of tyrosine hydroxylase immunoreactivity within the 15 gauge VTA punch, the doughnut contained much lower levels of tyrosine hydroxylase (not shown). These data indicate that morphine regulation of NFs is localized either within the A10 dopaminergic neurons themselves, or within neuronal elements in close proximity to the dopaminergic cells of the VTA (see Discussion).

\section{Lack of effect of other psychotropic drugs and} chronic stress on NFs in the VTA

The pharmacological specificity of NF regulation in the VTA was evaluated next. Rats were treated chronically with either imipramine or haloperidol, two psychotropic drugs without reinforcing properties. Neither imipramine, an antidepressant drug, nor haloperidol, an antipsychotic drug, altered NFs in the VTA after chronic treatment as measured by immunoblot analysis. The possibility that NF regulation could be stress related was also considered. However, chronic cold stress, a procedure known to induce a number of biochemical alterations in the brain noradrenergic system (Richard et al., 1988; Melia et al., 1992), did not produce any significant changes in NF levels in the VTA. These data are summarized in Figure 9. In addition, chronic implantation of placebo morphine pellets produced no detectable changes in NF-200, NF-160, NF-68, or NF-66 as measured by direct back phosphorylation (data not shown), providing further evidence against a stress-related effect.

\section{Discussion}

This study examines the involvement of NFs in the chronic actions of morphine and cocaine in the VTA, a brain region that plays a critical role in mediating the rewarding properties of opiates, cocaine, and other drugs of abuse. We show that chronic morphine and chronic cocaine share the common action of decreasing levels of NF-200, NF-160, and NF-68 in this dopaminergic brain reward region, an effect not seen after acute morphine or cocaine administration. NFs were not altered in response to chronic treatment with imipramine or haloperidol, two psychotropic drugs without reinforcing properties, or by chronic cold or surgical stress. In contrast to NFs, levels of $\alpha$ - and $\beta$-tubulin, tau, actin, vimentin, synaptophysin, and synapsin I were not altered by chronic morphine treatment in the VTA, suggesting that morphine regulation of NFs does not reflect a general disruption of the neuronal cytoskeleton within this brain region. The results are consistent with the possibility that a specific downregulation of NFs may represent part of a common molecular basis for morphine and cocaine addiction mediated by the VTA.

In these studies, we have assayed NFs in three ways: by back phosphorylation, immunolabeling, and Coomassie blue staining. Taken together, the three measurements indicate that chronic morphine and chronic cocaine decrease the total amounts of NF-200, NF-160, and NF-68 in the VTA. We also found that chronic morphine and cocaine produced an apparent increase in the phosphorylation state of NF-200 and NF-160, by using SMI-31, a monoclonal antibody specific to the highly phosphorylated forms of these proteins. It is not known whether NF68 is also increased in phosphorylation state, as phosphorylation-specific antibodies to this protein are presently unavailable, presumably due to the much lesser degree of phosphorylation of this protein (1-3 mol $\mathrm{PO}_{4} / \mathrm{mol}$ protein) compared to NF-160 (8-26 mol PO $4 / \mathrm{mol}$ protein) and NF-200 (13-104 $\mathrm{mol} \mathrm{PO}_{4} / \mathrm{mol}$ protein) (Shaw, 1991).

Table 2. Regional specificity of chronic morphine regulation of NF proteins

\begin{tabular}{lccr}
\multicolumn{4}{l}{ NF immunoreactivity } \\
\cline { 2 - 4 } & NF-200 & NF-160 & NF-68 \\
\hline VTA & $82 \pm 9(7)$ & $67 \pm 9(12)^{*}$ & $86 \pm 4(10)^{*}$ \\
SN & $100 \pm 16(10)$ & $109 \pm 11(12)$ & $102 \pm 6(14)$ \\
LC & $100 \pm 7(10)$ & $102 \pm 9(9)$ & $110 \pm 9(9)$ \\
Midbrain ${ }^{a}$ & $101 \pm 21(5)$ & $96 \pm 20(5)$ & $99 \pm 9(6)$ \\
VTA "doughnuts" $b$ & $103 \pm 17(6)$ & $106 \pm 14(6)$ & $100 \pm 10(6)$ \\
Spinal cord & $104 \pm 8(6)$ & $103 \pm 7(6)$ & $97 \pm 3(6)$
\end{tabular}

Data are presented as percentage of control $\pm \mathrm{SEM} ; N$ is given in parentheses.

${ }^{a}$ Midbrain: coronal sections of midbrain at the level of the VTA from which VTA and SN nuclei have been excised.

${ }^{b}$ VTA "doughnuts": 12 gauge punches of tissue surrounding 15 gauge punches of VTA nuclei.

${ }^{*} p<0.05$ by $\chi^{2}$ test. 


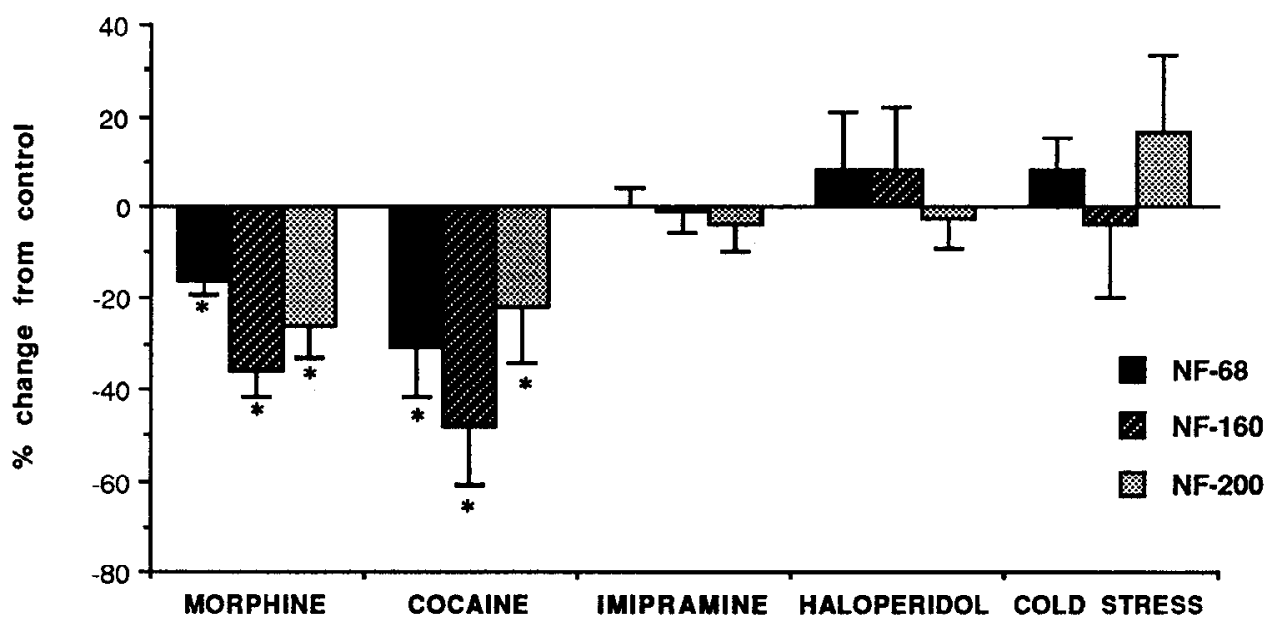

Figure 9. Pharmacological specificity of morphine and cocaine regulation of NFs in the VTA. Rats were treated chronically with either morphine, cocaine, imipramine, or haloperidol or were subjected to $5 \mathrm{~d}$ of cold stress, as described in Materials and Methods. Total cellular extracts of VTA were isolated from control and treated rats and subjected to SDS-PAGE. Levels of NF200, NF-160, and NF-68 were determined by immunolabeling or Coomassie blue staining, as described in Materials and Methods. Data are expressed as percentage difference from control and represent the mean \pm SEM from 5-15 rats in each treatment group. $*, p<0.05$ by $\chi^{2}$ test.
It is uncertain what impact such alterations in NFs would have on the functional properties of the VTA. NFs are known to be associated with axonal transport (Hoffman and Lasek, 1975; Tytell et al., 1981; Hammerschlag and Brady, 1989), although the precise role subserved by NF proteins remains unknown. A variety of in vivo manipulations, including axotomy, aluminum intoxication, and chronic $\beta, \beta^{\prime}$-iminodipropionitrile intoxication are all known to lead to decreased NF levels and to decreased rates of axonal transport (Hoffman et al., 1984; Tronosco et al., 1985; Goldstein et al., 1987; Watson et al., 1989). Furthermore, increased phosphorylation of NFs is also correlated with decreased rates of axonal transport. There is a progressive increase in the degree of phosphorylation of NFs as they are transported from the cell body along the axon (Sternberger and Sternberger, 1983; Hoffman et al., 1985; Carden et al., 1987; Nixon et al., 1987; Pestronk et al., 1990), which has been proposed to be the mechanism by which NF velocity becomes progressively decreased as NF proteins are concomitantly transported distally (Carden et al., 1987; Lee et al., 1987). In addition, in vivo axotomy (Goldstein et al., 1987) and chronic $\beta, \beta^{\prime}$-iminodipropionitrile intoxication (Watson et al., 1989) also lead to increased phosphorylation of NFs, in concert with decreasing total levels of these proteins. Finally, NFs from rats made experimentally diabetic exist in an increased state of phosphorylation (Pekiner and McLean, 1991), which also correlates with the decreased axonal transport rates observed in diabetic animals (Macioce et al., 1989).

Given the above evidence, our findings that NFs are (1) decreased in total amount and (2) present in an increased state of phosphorylation in the VTA after chronic morphine and cocaine treatments imply conditions of decreased axonal transport within this brain region. Indeed, we have recently found that chronic morphine does impair axonal transport in the mesolimbic dopamine system (Beitner-Johnson and Nestler, 1992). This finding may be related to our previous demonstration, that although chronic morphine and cocaine increase levels of tyrosine hydroxylase immunoreactivity in VTA cell bodies, there is not a corresponding increase in tyrosine hydroxylase immunoreactivity in the dopaminergic nerve terminals in the nucleus accumbens (Beitner-Johnson and Nestler, 1991). Because tyrosine hydroxylase in the NAc is localized virtually entirely in nerve terminals derived from the VTA (Swanson, 1982), the lack of correspondingly elevated enzyme levels in NAc terminals could be explained by slower or less effective transport of the enzyme along these dopaminergic axons. Taken together, our findings suggest the possibility that chronic use of morphine or cocaine may alter the structural features of mesolimbic dopamine neurons in such a way as to reduce the ability of these cells to transmit dopaminergic signals to neuronal elements in the NAc. According to this view, long-term opiate or stimulant use might impair the brain's endogenous reward system, which could have a major impact on motivation and drug-seeking behavior. Our similar findings with Lewis and Fischer 344 rats (see below) suggest that populations that are genetically predisposed to drug addiction may have a similar type of mesolimbic dopamine impairment inherently. Although much further work is needed to study the validity of these and many other interpretations, the findings indicate that alterations in NFs reflect (and possibly underlie) a common functional effect of chronic morphine and chronic cocaine in the VTA (for further discussion, see BeitnerJohnson et al., 1992).

In contrast to NF-200, NF-160, and NF-68, regulation of NF66 was different in response to chronic morphine and cocaine treatments. While chronic cocaine decreased the total amount of NF-66, chronic morphine induced an apparent increase in phosphorylation state of the protein without a change in its total amount. This may be related to some of the distinct actions of morphine and cocaine in the VTA. Systemic morphine and cocaine have opposite acute electrophysiological actions on VTA neurons (excitatory vs. inhibitory) (Matthews and German, 1984; Einhorn et al., 1988), as well as markedly different acute behavioral effects (sedative vs. stimulant). On the other hand, a morphine-induced increase in phosphorylation state of NF-66 could be functionally equivalent to a decrease in the total amount of this protein, based on the studies of NF-160 and NF-200 phosphorylation and axonal transport, as described above. However, as of yet, little is known about the function of NF66 , other than that it is a neural-specific protein that shares homology with the three major NFs and can assemble into 10 $n m$ (i.e., in termediate) filaments in vitro (Chiu et al., 1989; Flienger et al., 1990).

NFs were studied here by back phosphorylation with purified cAMP-dependent protein kinase. The three major NF proteins, NF-200, NF-160, and NF-68, have been reported to be phosphorylated both in vivo and in vitro by multiple protein kinases, including cAMP-dependent protein kinase, calcium/calmodulin-dependent protein kinase, protein kinase $\mathrm{C}$, and a cAMP/ calcium-independent NF-associated protein kinase (Leterrier et 
al., 1981; Vallano et al., 1985; Pant et al., 1986; Sihag et al., 1988). The protein kinase(s) responsible for morphine and cocaine regulation of NF phosphorylation in vivo remains unknown. The phosphorylation of NF-66 has not yet been characterized. We have found that NF-66 is phosphorylated by an endogenous calcium/calmodulin-dependent protein kinase activity in subcellular fractions of brain, but is not an endogenous substrate for cAMP-dependent protein kinase (D. Beitner-Johnson, X. Guitart, and E. J. Nestler, unpublished observations). This probably explains why the majority of NF-66 remains in a nonphosphorylated state even after back phosphorylation with purified cAMP-dependent protein kinase (see Fig. $3 F$ ). There is a preliminary report of the phosphorylation of NF- 66 by several protein kinases in vitro (Nixon et al., 1990); however, the protein kinase that regulates the phosphorylation of this protein in vivo remains unknown.

One important issue raised by this study, as alluded to above, is the cellular localization of the morphine- and cocaine-induced decreases in NF levels. Several pieces of evidence suggest that drug regulation of NFs may occur within dopaminergic neurons themselves. First, drug regulation of NFs was observed only in the VTA, a brain region enriched in dopaminergic neurons known to play a critical role in both opiate and cocaine reward (Roberts and Koob, 1982; Bozarth and Wise, 1984; Bozarth, 1986). Second, chronic morphine and cocaine increase levels of tyrosine hydroxylase specifically in the VTA (Bcitner-Johnson and Nestler, 1991). This demonstrates that the drugs do indeed produce some alterations in VTA dopaminergic neurons. Third, we also demonstrated previously that levels of tyrosine hydroxylase in the VTA are higher in Lewis rats versus Fischer rats (BeitnerJohnson et al., 1991), and that levels of NFs in the VTA are lower in Lewis versus Fischer rats (Guitart et al., 1992). This further establishes some association between higher levels of tyrosine hydroxylase and lower levels of NFs in the VTA, and could suggest the involvement of the same cell type in both phenomena. Of course, the VTA is a heterogeneous region (Phillipson, 1979; Poirier et al., 1983), and it is possible that drug regulation of NFs may be occurring in other neuronal elements located in this area. However, the fact that no change in NFs was observed in the "doughnut" of tissue directly surrounding the VTA indicates that if morphine and cocaine regulation of NFs does not occur within VTA dopaminergic neurons, then such drug regulation would be occurring either in neuronal cell types or in specific populations of axonal processes particular to this region. In any event, morphine and cocaine regulation of NFs in these non-dopaminergic elements, or in the dopaminergic neurons themselves, would be expected to have important implications for the functional effects of these drugs on the VTA.

The findings of this study establish that NF proteins represent a previously unknown target of chronic opiate and chronic cocaine action. Although the functional consequences of decreased NFs remain to be established, the results raise the exciting possibility of morphine- and cocaine-induced changes in VTA structure and function. As cited above, we have found differences in basal levels of NFs and tyrosine hydroxylase in Lewis versus Fischer rats (Beitner-Johnson et al., 1991; Guitart et al., 1992), two genetically inbred strains that exhibit different preferences for opiates, cocaine, and alcohol (Li and Lumeng, 1984; Suzuki et al., 1988; George and Goldberg, 1989; Terwilliger et al., 1991b). Together, these findings support the hypothesis that regulation of NFs and tyrosine hydroxylase could represent common mechanisms by which these drugs alter mesolimbic dopamine function and thereby produce aspects of drug addiction.

\section{References}

Aghajanian GK (1978) Tolerance of locus coeruleus neurones to morphine and suppression of withdrawal response by clonidine. Nature 267:186-188.

Babbini M, Davis WM (1972) Time-dose relationships for locomotor activity effects of morphine after acute or repeated treatment. $\mathrm{Br} \mathbf{J}$ Pharmacol 46:213-224.

Beitner-Johnson D, Nestler EJ (1991) Morphine and cocaine exert common chronic actions on tyrosine hydroxylase in dopaminergic brain reward regions. J Neurochem 57:344-347.

Beitner-Johnson D, Nestler EJ (1992) Chronic morphine impairs axonal transport in the rat mesolimbic dopamine system. Soc Neurosci Abstr 18, in press.

Beitner-Johnson D, Guitart X, Nestler EJ (1991) Dopaminergic brain reward regions of Lewis and Fischer rats display different levels of tyrosine hydroxylase and other morphine and cocaine-regulated phosphoproteins. Brain Res 561:147-150.

Beitner-Johnson D, Guitart X, Nestler EJ (1992) Common intracellular actions of chronic morphine and cocaine in dopaminergic brain reward regions. Ann NY Acad Sci, in press.

Blasig J, Herz A, Reinhold K, Zieglgansberger S (1973) Development of physical dependence on morphine in respect to time and dosage and quantification of the precipitated withdrawal syndrome in rats. Psychopharmacologia 33:19-38.

Bozarth MA (1986) Neural basis of psychomotor stimulant and opiate reward: evidence suggesting the involvement of a common dopaminergic system. Behav Brain Res 22:107-116.

Bozarth MA, Wise RA (1984) Anatomically distinct opiate receptor fields mediate reward and physical dependence. Science 224:516-517.

Bozarth MA, Wise RA (1986) Involvement of the ventral tegmental dopamine system in opioid and psychomotor stimulant reinforcement. In: National Institute on Drug Abuse Research Monograph 67, Problems of drug dependence, 1985 (Harris LS, ed), pp 190-196. Washington, DC: U.S. Government Printing Office.

Brock JW, Ng JP, Justice JB Jr (1990) Effect of chronic cocaine on dopamine synthesis in the nucleus accumbens as determined by microdialysis with NSD-1015. Neurosci Lett 117:234-239.

Brown BA, Nixon RA, Strocchi P, Marotta CA (1981) Characterization and comparison of neurofilament proteins from rat and mouse CNS. J Neurochem 36:143-153.

Carden MJ, Schlaepfer WW, Lee VM-Y (1985) The structure, biochemical properties, and immunogenicity of neurofilament peripheral regions are determined by phosphorylation state. J Biol Chem 260: 9805-9817.

Carden MJ, Trojanowski JQ, Schlaepfer WW, Lee VM-Y (1987) Twostage expression of neurofilament polypeptides during rat neurogenesis with early establishment of adult phosphorylation patterns. J Neurosci 7:3489-3504.

Carr GK, Fibiger HC, Phillips AG (1989) Conditioned place preference as a measure of drug reward. In: The neuropharmacological basis of reward (Liebman JM, Cooper SJ, eds), pp 264-319. New York: Oxford UP.

Chen J, Paredes W, Li J, Smithe D, Lowinson J, Gardner EL (1990) $\Delta^{9}$-tetrahydrocannabinol produces naloxone-blockable enhancement of presynaptic basal dopamine efflux in nucleus accumbens of conscious, freely-moving rats as measured by intracerebral microdialysis. Psychopharmacology 102:156-162.

Chiodo LA, Bunney BS (1983) Typical and atypical neuroleptics: differential effects of chronic administration on the activity of $A 9$ and A10 midbrain dopaminergic neừons. J Neurosci 3:1607-1619.

Chiu F-C, Barnes EA, Das K, Haley J, Socolow P, Macaluso FP, Fant $J$ (1989) Characterization of a novel $66 \mathrm{kd}$ subunit of mammalian neurofilaments. Neuron 2:1435-1445.

Cleveland DW, Fischer SG, Kirschner MW, Laemmli UK (1977) Peptide mapping by limited proteolysis in sodium dodecyl sulfate and analysis by gel electrophoresis. J Biol Chem 252:1102-1106.

DiChiara G, Impcrato A (1988) Drugs abused by humans preferentially increase synaptic dopamine concentrations in the mesolimbic system of freely moving rats. Proc Natl Acad Sci USA 85:5274-5278. 
Einhorn LC, Johansen PA, White FJ (1988) Electrophysiological effects of cocaine in the mesoaccumbens dopamine system: studies in the ventral tegmental area. $J$ Neurosci 8:100-112.

Fibiger HC (1978) Drugs and reinforcement mechanisms: a critical review of the catecholamine theory. Annu Rev Pharmacol Toxicol $18: 37-56$

Flienger KH, Ching GY, Liem RKH (1990) The predicted amino acid sequence of $\alpha$-internexin is that of a novel neuronal intermediate filament protein. EMBO J 9:745-759.

George FR, Goldberg SR (1989) Genetic approaches to the analysis of addiction processes. Trends Pharmacol Sci 10:78-83.

Goldstein ME, Cooper HS, Bruce J, Carden MJ, Lee VM-Y, Schlaepfer WW (1987) Phosphorylation of neurofilament proteins and chromatolysis following transection of rat sciatic nerve. J Neurosci 7 : 1586-1594.

Guitart X, Nestler EJ (1989) Identification of morphine- and cyclic AMP-regulated phosphoproteins (MARPPs) in the locus coeruleus and other regions of rat brain: rcgulation by acute and chronic morphine. J Neurosci 9:4371-4387.

Guitart X, Beitner-Johnson D, Marby DW, Kosten TA, Nestler EJ (1992) Fischer and Lewis rats differ in basal levels of neurofilament proteins and their regulation by chronic morphine in the mesolimbic dopamine system. Synapse, in press.

Hall GF, Lee VM-Y, Kosik KS (1991) Microtubule destabilization and neurofilament phosphorylation precede dendritic sprouting after close axotomy of lamprey central neurons. Proc Natl Acad Sci USA 88:5016-5020.

Hammerschlag R, Brady ST (1989) Axonal transport and the neuronal cytoskeleton. In: Basic neurochemistry, 4th ed (Siegel G, Agranoff B Albers RW, Molinoff P, eds), pp 457-478. New York: Raven.

Henry DJ, Greene MA, White FJ (1989) Electrophysiological effects of cocaine in the mesoaccumbens dopamine system: repeated ad ministration. J Pharmacol Exp Ther 251:833-839.

Hoffman PN, Lasek RJ (1975) Identification of major structural polypeptides of the axon and their generality among mammalian neurons J Cell Biol 66:351-366.

Hoffman PN, Griffin JW, Price DL (1984) Control of axonal caliber by neurofilament transport. J Cell Biol 99:705-714.

Hoffman PN, Griffin JW, Gold BS, Price DL (1985) Slowing of neurofilament transport and the radial growth of developing nerve fibers. J Neurosci 5:2920-2929.

Jaffe JH (1990) Drug addiction and drug abuse. In: The pharmacological basis of therapeutics (Gilman AG, Rall TW, Nies AS, Taylor $P$, eds), pp 522-573. New York: Permagon.

Julien J-P, Mushynski WE (1982) Multiple phosphorylation sites in mammalian neurofilament polypeptides. J Biol Chem 257:1046710470.

Kalivas PW, Duffy P (1988) Effects of daily cocaine and morphine treatment on somatodendritic and terminal field dopamine release. $\mathrm{J}$ Neurochem 50:1498-1504.

Kilbey MM, Ellinwood EH (1977) Administration of stimulant drugs: response modification. In: Cocaine and other stimulants (Ellinwood EH, Kilbey MM, eds), pp 404-429. New York: Plenum.

Koob GF, Bloom FE (1988) Cellular and molecular mechanisms of drug dependence. Science 242:715-723.

Lee VM-Y, Carden MJ, Schlaepfer WW, Trojanowski JQ (1987) Monoclonal antibodies distinguish several differentially phosphorylated states of the two largest rat neurofilament subunits (NF-H and NF-M) and demonstrate their existence in the normal nervous system of adult rats. J Neurosci 7:3474-3488.

Leterrier J-F, Liem RKH, Shelanski ML (1981) Preferential phosphorylation of the 150,000 molecular weight component of neurofilaments by a cyclic-AMP-dependent, microtubule-associated protein kinase. J Cell Biol 90:755-760.

Lett BT (1989) Repeated exposures intensify rather than diminish the rewarding effects of amphetamine, morphine, and cocaine. Psychopharmacology (Berl) 98:357-362.

Li T-K, Lumeng L (1984) Alcohol preference and voluntary alcohol intakes of inbred rat strains and the NIH heterogeneous stock of rats. Alcohol Clin Exp Res 8:485-486.

Liebman JM, Cooper SJ, eds (1989) The neuropharmacological basis of reward. New York: Oxford UP.

Lowry OH, Rosebrough NI, Farr AL, Randall RJ (1951) Protein measurement with the folin phenol reagent. J Biol Chem 193:265275.
Lyness WH, Friedle NM, Moore KE (1979) Destruction of dopaminergic nerve terminals in nucleus accumbens: effect of $D$-amphetamine self-administration. Pharmacol Biochem Behav 11:553-556.

Macioce P, Filliatreau G, Figliomeni B, Hassig R, Theiry J, Di Biamberardino L (1989) Slow axonal transport impairment of cytoskeletal proteins in streptozocin-induced diabetic neuropathy. J Neurochem 53:1261-1267.

Matthews RT, German DC (1984) Electrophysiological evidence for excitation of rat ventral tegmental area dopamine neurons by morphine. Neuroscience 11:617-625.

Melia KR, Rasmussen K, Terwilliger RZ, Haycock JW, Nestler EJ, Duman RS (1992) Coordinate regulation of the cyclic AMP system with firing rate and expression of tyrosine hydroxylase in the rat locus coeruleus: effects of chronic stress and drug treatments. J Neurochem 58:494-502.

Nestler EJ, Greengard P (1984) Protein phosphorylation in the nervous system. New York: Wiley.

Nestler EJ, Greengard P (1989) Protein phosphorylation and the regulation of neuronal function. In: Basic neurochemistry, 4th ed (Siegel G, Agranoff B, Albers RW, Molinoff P, eds), pp 373-398. New York: Raven.

Nestler EJ, Tallman JF (1988) Chronic morphine treatment increases cyclic AMP-dependent protein kinase activity in the rat locus coeruleus. Mol Pharmacol 33:127-132.

Nestler EJ, McMahon A, Sabban EL, Tallman JF, Duman RS (1990a) Chronic antidepressant administration decreases the expression of tyrosine hydroxylase in the rat locus coeruleus. Proc Natl Acad Sci USA 87:7522-7526.

Nestler EI, Terwilliger RZ, Walker JR, Sevarino KA, Duman RS (1990b) Chronic cocaine treatment decreases levels of the $G$ protein subunits $\mathrm{Gi} \alpha$ and $\mathrm{Go} \alpha$ in discrete regions of the rat brain. J Neurochem 55:1079-1082.

$\mathrm{Ng} \mathrm{JP}$, Hubert GW, Justice JB Jr (1991) Increased stimulated release and uptake of dopamine in nucleus accumbens after repeated cocaine administration as measured by in vivo voltammetry. J Neurochem 56:1485-1492.

Nixon RA, Lewis SE, Marotta CA (1987) Posttranslational modification of neurofilament proteins by phosphate during axoplasmic transport in retinal ganglion cell neurons. J Neurosci 7:1145-1158.

Nixon RA, Patman V, Chiu F-C, Sihag R (1990) Axonal transport and modification of the $64 \mathrm{kDa}$ intermediate filament protein in retinal ganglion cells. J Cell Biol [Suppl] 11:434a.

O'Farrell PH (1975) High resolution two-dimensional electrophoresis of proteins. J Biol Chem 250:4007-4021.

Palkovits M, Brownstein M (1988) Maps and guide to microdissection of the rat brain. New York: Elsevier.

Pant HC, Gallant PE, Gainer H (1986) Characterization of a cyclic nucleotide- and calcium-independent neurofilament protein kinase activity in axoplasm from the squid giant axon. J Biol Chem 261: 2968-2977.

Pekiner C, McLean G (1991) Neurofilament protein phosphorylation in spinal cord of experimentally diabetic rats. J Neurochem 56:13621367.

Pestronk A, Watson DF, Yuan CM (1990) Neurofilament phosphorylation in peripheral nerve: changes with axonal length and growth state. J Neurochem 54:977-982.

Peltit HO, Ettenberg A, Bloom FE, Koob GF (1984) Destruction of dopamine in the nucleus accumbens selectively attenuates cocaine but not heroin self-administration in rats. Psychopharmacology (Berl) 84:167-173.

Pettit HO, Pan H, Parsons LH, Justice JB Jr (1990) Extracellular concentrations of cocaine and dopamine are enhanced during chronic cocaine administration. J Neurochem 55:798-804.

Phillipson OT (1979) The cytoarchitecture of the interfascicular nucleus and ventral tegmental area of Tsai in the rat. J Comp Neurol 187:85-98.

Piazza PV, Deminiere J-M, Le Moal M, Simon H (1989) Factors that predict individual vulnerability to amphetamine self-administration. Science 245:1511-1514.

Poirier LJ, Giguere M, Marchand R (1983) Comparative morphology of the substantia nigra and ventral tegmental area in the monkey, cat and rat. Brain Res Bull 11:371-397.

Post RM, Rose H (1976) Increasing effects of repetitive cocaine administration in the rat. Nature 260:731-732.

Rasmussen K, Beitner-Johnson DB, Krystal JH, Aghajanian GK, Nes- 
tler EJ (1990) Opiate withdrawal and the rat locus coeruleus: behavioral, electrophysiological, and biochemical correlates. J Neurosci 10:2308-2317.

Richard F, Faucon-Biguet N, Labatut R, Rollet D, Mallet J, Buda M (1988) Modulation of tyrosine hydroxylase gene expression in rat brain and adrenals by exposure to cold. J Neurosci Res 20:32-37.

Roberts DCS, Koob GF (1982) Disruption of cocaine self-administration following 6-hydroxydopamine lesions of the ventral tegmental area in rats. Pharmacol Biochem Behav 17:901-904.

Robinson PA, Anderton BH (1988) Neurofilament probes-a review of neurofilament distribution and biology. Rev Neurosci 2:1-40.

Shaw G (1991) Neurofilament proteins. In: The neuronal cytoskeleton (Burgoyne RD, ed), pp 185-214. New York: Wiley-Liss.

Sihag RK, Jeng AY, Nixon RA (1988) Phosphorylation of neurofilament proteins by protein kinase C. FEBS Lett 233:181-185.

Spyraki C, Fibiger HC, Phillips AG (1983) Attenuation of heroin reward in rats by disruption of the mesolimbic dopamine system. Psychopharmacology (Berl) 79:278-283.

Stekatee JD, Striplin CD, Murray TF, Kalivas PW (1991) Possible role for G-proteins in behavioral sensitization to cocaine. Brain Res 545:287-291.

Sternberger LA, Sternberger NH (1983) Monoclonal antibodies distinguish phosphorylated and non-phosphorylated forms of neurofilaments in situ. Proc Natl Acad Sci USA 80:6126-6130.

Suzuki T, George FR, Meisch RA (1988) Differential establishment and maintenance of oral ethanol reinforced behavior in Lewis and Fischer 344 inbred rat strains. J Pharmacol Exp Ther 245:164-170.

Swanson LW (1982) The projections of the ventral tegmental area and adjacent regions: a combined fluorescent retrograde tracer and immunofluorescence study in the rat. Brain Res Bull 9:321-353.

Terwilliger R, Beitner-Johnson D, Sevarino KA, Crain SM, Nestler FJ (1991a) A general role for adaptations in G-proteins and the cyclic AMP system in mediating the chronic actions of morphine and cocaine on neuronal function. Brain Res 548:100-110.

Terwilliger RZ, Bradberry C, Guitart X, Beitner-Johnson D, Marby D, Kosten TA, Roth RH, Nestler EJ (1991b) Lewis and Fischer 344 rats and drug addiction: behavioral and biochemical correlates. Soc Neurosci Abstr 17:823.

Tronosco JC, Hoffman PN, Griffin JW, Hess-Kozlow KM, Price DL (1985) Aluminum intoxication: a disorder of neurofilament transport in motor neurons. Brain Res 342:172-175.

Tytell M, Black MM, Garner JA, Lasek RJ (1981) Axonal transport: each major component reflects the movement of distinct macromolecular complexes. Science 214:179-181.

Vallano ML, Buckholz TM, Lorenzo RJ (1985) Phosphorylation of neurofilament proteins by endogenous calcium/calmodulin dependent protein kinase. Biochem Biophys Res Commun 130:957-963.

Watson DF, Griffin JW, Fittro KP, Hoffman PN (1989) Phosphorylation-dependent immunoreactivity of neurofilaments increases during axonal maturation and $\beta, \beta^{\prime}$-iminodipropionitrile intoxication. $\mathrm{J}$ Neurochem 53:1818-1829.

Wise RA, Bozarth MA (1987) A psychomotor stimulant theory of addiction. Psychol Rev 94:469-492.

Zito K, Vickers G, Roberts DCS (1985) Disruption of cocaine and heroin self-administration following kainic acid lesions of the nucleus accumbens. Pharmacol Biochem Behav 23:1029-1036. 